\title{
Penguatan Kelembagaan Petani Padi dalam Pengambilan Keputusan Adopsi Teknologi IPB Prima
}

\section{Institutional Improvement of Rice Farmers for Making Decision in IPB Prima Technology Adoption}

\author{
Khairunnisa ${ }^{1}$, Amiruddin $\mathrm{Saleh}^{2}$, Oos M Anwas ${ }^{3}$ \\ ${ }^{1}$ Program Studi Ilmu Penyuluhan Pembangunan, Sekolah Pascasarjana, Institut Pertanian Bogor, Bogor \\ ${ }^{2}$ Departemen Sains Komunikasi dan Pengembangan Masyarakat, Fakultas Ekologi Manusia, Institut Pertanian Bogor, Bogor
}

\begin{abstract}
Farmers' institutional improvement is an effort to help with their decisions on the adoption of an innovation. Becoming members of farmer groups will facilitate farmers to be able to manage, understand, and implement an innovation. This study aims to analyze the influence of farmers' institutional improvement on the adoption of IPB Prima Technology by rice farmers. This study uses a quantitative and quantitative approach with a survey method and questionnaires for data collectionl. Respondents in this study (50 people) were all members of the farmer group involved in cultivating IPB 3S variety of rice. Data was collected in July 2018 and analyzed using the Statistical Product and Service Solutions (SPSS) version 23 for descriptive and inferential statistics. The results showed that farmers agreed that farmers' institutions have the roles in strengthening the institutional structure, improving the members' capacity in the development of agribusiness, and improving their institutional capacity in carrying out their functions. In terms of Prima IPB Technology adoption, farmers have reused straw on agricultural land and have cultivated rice plants according to IPB Best-Practices, but they have never decomposed straw using decomposers and still rarely adopt agricultural mechanization. The farmers' improved institutional capacity in carrying out their functions significantly influences the application of IPB Bio and IPB Best-Practices. Further, the improvement of the members'ability in developing agribusiness, especially the time efficiency, has a significant negative effect on the reuse of straw, i.e. burning straw on farming land.
\end{abstract}

Keywords: Farmer Institution, IPB Prima Technology, IPB 3S Variety Rice

\begin{abstract}
Abstrak
Penguatan kelembagaan petani merupakan upaya meningkatkan keputusan adopsi petani terhadap suatu inovasi. Petani yang tergabung dalam kelompok tani akan lebih mudah untuk mengelola agar tahu, mau, dan mampu menerapkan inovasi. Penelitian ini bertujuan untuk menganalisis pengaruh penguatan kelembagaan petani terhadap keputusan adopsi Teknologi IPB Prima oleh petani padi. Penelitian ini menggunakan pendekatan kuantitatif dan kualitatif dengan metode survei dan kuesioner sebagai alat pengumpulan data. Responden dalam penelitian ini merupakan seluruh anggota kelompok tani yang berpartisipasi dalam kegiatan budidaya padi varietas IPB 3S, yaitu sebanyak 50 orang. Data dikumpulkan pada bulan Juli 2018. Data dianalisis menggunakan Statistical Product and Service Solutions (SPSS) versi 23 untuk statistik deskriptif dan statistik inferensial. Hasil penelitian menunjukkan bahwa petani setuju kelembagaan petani berfungsi sebagai penguatan struktur kelembagaan petani, peningkatan kemampuan anggota dalam pengembangan agribisnis dan peningkatan kemampuan kelembagaan petani dalam menjalankan fungsinya. Pada keputusan petani untuk mengadopsi Teknologi Prima IPB, para petani telah menggunakan kembali jerami di lahan pertanian dan telah membudidayakan tanaman padi sesuai dengan IPB Best-Practice, tetapi petani tidak pernah mendekomposer jerami menggunakan dekomposer dan masih jarang dalam penerapan mekanisasi pertanian. Peningkatan kemampuan kelembagaan petani dalam menjalankan fungsinya berpengaruh nyata terhadap aplikasi IPB Bio dan pelaksanaan IPB Best-Practice. Selannjutnya, peningkatan kemapuan anggota dalam pengembangan agribisnis khususnya efisiensi waktu berpengaruh nyata negatif terhadap pemanfaatan kembali jerami, dengan membakar jerami di lahan pertanian.
\end{abstract}

Kata kunci: Kelembagaan Petani, Teknologi IPB Prima, Padi Varietas IPB 3S

\section{Pendahuluan}

Keberadaan teknologi produksi padi menjadi harapan baru bagi petani agar dapat meningkatkan produktivitas dan pendapatan petani padi. Teknologi usahatani padi

${ }^{1}$ Korespondensi penulis

E-mail: nessapiliang@gmail.com sudah lama diperkenalkan kepada petani, namun belum dimanfaatkan secara optimal, hal ini disebabkan masih tingginya tingkat kepercayaan petani melakukan pengelolaan usahatani padi secara turun temurun dan menggunakan teknologi yang terbatas. Hal ini senada 
dengan pendapat Soekartawi (2005) dalam Nirwani et al. (2012) bahwa perkembangan objek tertentu memerlukan komunikasi yang lebih spesifik, baik secara perorangan maupun kelompok yang bersifat umum dengan menggunakan lambang-lambang agar pernyataan dapat tersampaikan.

Menurut Anantanyu (2011) kelembagaan petani diharapkan mampu membantu petani keluar dari persoalan kesenjangan ekonomi petani, namun sampai saat ini masih belum berfungsi secara optimal. Diperlukan penguasaan teknologi pertanian yang memadai dan kemampuan bersaing dari para petani agar mampu bertahan terhadap permintaan pasar. Keberadaan kelompok tani sangat membantu petani dalam mengakses informasi, sarana produksi, dan sebagai wahana belajar. Namun sebuah kelompok tani juga membutuhkan penguatan agar mampu berkembang dan siap dalam menerima inovasi baru.

Hasil penelitian terdahulu menunjukkan bahwa penguatan kelembagaan petani belum sepenuhnya mampu meningkatkan keputusan petani dalam mengadopsi suatu inovasi sehingga kesejahteraan petani meningkat. Sebagaimana menurut Prasetyo et al. (2016) peran kelembagaan tidak memiliki pengaruh dengan tingkat adopsi teknologi peternak di Kelompok Ternak Lembah Meru, namun hasil analisis korelasi menunjukkan nilai yang positif. Hal ini berbeda dengan Zakaria (2009) yang menyampaikan bahwa pemberdayaan kelompok tani merupakan serangkaian upaya yang sistematis, konsisten dan berkelanjutan untuk meningkatkan daya adaptasi dan inovasi petani guna memanfaatkan teknologi secara optimal.

Pada tahun 2012, IPB (Institut Pertanian Bogor) berhasil menciptakan teknologi terbarukan varietas padi yang mampu mencapai produksi hingga 13,4 ton/ha. Padi ini diberi nama "Varietas IPB 3S". Varietas Padi tersebut diciptakan khusus bersifat PTB (Padi Tipe Baru) dengan berbagai karakteristik yang berbeda dari benih padi VUB (Varietas Unggul Baru). Rata-rata populasi tanaman padi dalam satu hektar berjumlah \pm 330.000 anakan, dengan hasil produksi lebih tinggi rata-rata hingga 1-2 ton/ha. (Aswidinnor et al. 2016). Namun varietas tersebut membutuhkan paket teknologi khusus agar mampu mencapai produktivitas optimal. LPPM IPB menawarkan paket Teknologi IPB Prima yang disebut dengan istilah "lima pilar produktivitas tinggi dan lestari."

Paket Teknologi IPB Prima terdiri dari: 1) Restorasi lahan dengan jerami; 2) Aplikasi IPB-BIO; 3) IPBBest practice; 4) Penerapan mekanisasi pertanian; 5) Pendampingan IPB dan Penyuluhan (LPPMIPB 2016). Paket teknologi ini dapat meningkatkan produktivitas padi dalam seiring dengan harapan Menteri Pertanian terwujudnya swasembada pangan di Indonesia. Teknologi produksi padi IPB Prima Teknologi ini bertujuan untuk mendukung program nasional produksi padi (surplus 10 juta ton beras/tahun) melalui pengembangan percontohan (show window) untuk mencapai produtivitas padi minimal 8,2 ton/ hektar (rata-rata kawasan).

Pada tahun 2016, Perguruan Tinggi (IPB, Unsyiah, Unimal), PPL, dan Dinas Pertanian Aceh Utara melaksanakan diseminasi uji adaptasi varietas IPB 3S pada petani penangkar benih di Desa Meunasah Pulo Kecamatan Sawang Kabupaten Aceh Utara. Pada dasarnya, budidaya tanaman padi varietas IPB 3S ini memiliki keunikan dari varietas padi lainnya yaitu dibutuhkannya kegiatan budidaya dengan paket Teknologi IPB Prima (restorasi lahan dengan jerami, aplikasi IPB-BIO, IPB-Best practice, dan penerapan mekanisasi pertanian). Varietas yang digunakan petani adalah varietas IPB 3S, dengan sistem tanam jajar Legowo 4:1 (20x10x40 cm) dan menggunakan bahan organik yang terdiri dari bakteri dekomposer, bakteri fungsional, dan agen hayati yang dapat merangsang pertumbuhan tanaman (LPPM IPB 2016).

Sistem usahatani yang selama ini digunakan petani di Kecamatan Sawang ialah sistem tanam jajar legowo dengan jarak tanam $20 \times 20 \mathrm{~cm}$. jumlah bibit yang digunakan perlobang tanam sebanyak 3-5 batang. Adapun jenis varietas yang digunakan kebanyakan merupakan varietas yang dianjurkan dari Dinas Pertanian setempat seperti Inpari-32, Ciherang, dan beberapa jenih galur murni. Namun sejauh ini hasil produktivitas padi hanya mampu mencapai tujuh ton/ha (Pusluhtan 2018), dengan demikian pihak Pemerintah, Penyuluh, Perguruan Tinggi dan Swasta bersinergi dalam meningkatkan produktivitas padi di Kecamatan Sawang tersebut. Salah satu hal yang dilakukan ialah melakukan kegiatan penyuluhan tentang varietas baru yang dihasilkan oleh Institut Pertanian Bogor, yang disebut dengan Varietas IPB 3S. 
Selama kegiatan produksi padi dengan Teknologi IPB Prima, petani didampingi oleh Penyuluh Pertanian Lapangan yang bekerjasama dengan pihak peneliti dari IPB. Kegiatan penyuluhan diawali dengan sosialisasi, pendampingan teknis budidaya, pasca panen, hingga pemasaran. Hasil produktivitas tanaman padi melalui teknologi inovasi IPB Prima di Kecamatan Sawang Kabupaten Aceh Utara mengalami peningkatan dari tahun 2016 sampai 2017 yaitu sekitar 2-3 ton/ha dan didapatkan produktivitas padi sebanyak 8,5 ton/ha (Zamzami 2017). Dengan demikian dapat dilihat bahwa varietas dan teknologi ini cocok untuk diterapkan di lahan petani di Kecamatan Sawang Provinsi Aceh. Namun berdasarkan data dari Balai Penyuluhan Pertanian Kecamatan Sawang saat ini petani sudah beralih ke varietas padi lain, sejak tidak ada lagi diberikan subsidi benih varietas IPB $3 \mathrm{~S}$.

Pada permasalahan dan potensi yang telah dijelaskan sebelumnya, dapat dilihat bahwa perlu dilakukan penguatan kelembagaan petani padi di Kecamatan Sawang Kabupaten Aceh Utara dengan tujuan agar kelembagaan petani dapat meningkatkan keputusan petani terhadap penerapan suatu inovasi. Penguatan kelembagaan petani penting dilakukan dalam rangka penguatan struktur kelembagaan petani, peningkatan kemampuan anggota dalam pengembangan agribisnis, peningkatan kemampuan kelembagaan petani dalam menjalankan fungsinya. Berdasarkan uraian tersebut, tujuan penelitian ini adalah menganalisis pengaruh penguatan kelembagaan petani terhadap keputusan adopsi Teknologi IPB Prima oleh petani padi sawah.

\section{Metode Penelitian}

Penelitian dilaksanakan di Desa Meunasah Pulo Kecamatan Sawang Kabupaten Aceh Utara. Penentuan daerah penelitian secara purposive pada Gabungan Kelompok Tani Sapu Pakat yang merupakan lokasi demplot penangkaran benih padi varietas IPB 3S dengan menggunakan Teknologi IPB Prima. Pengumpulan data dilakukan pada bulan Juli 2018. Jumlah sampel ditentukan secara sensus, dari 125 petani yang tergabung dalam Gabungan Kelompok Tani Sapu Pakat terdapat 50 orang petani yang mengikuti kegiatan pelatihan penangkaran benih varietas IPB 3S, dengan demikian seluruh petani tersebut menjadi responden dalam penelitian. Data primer diperoleh melalui hasil survei dan observasi di lapangan. Data sekunder dikumpulkan dari lembaga terkait seperti Balai Penyuluhan Pertanian Kecamatan Sawang, Dinas Pertanian dan Kehutanan Kabupaten Aceh Utara, Universitas Malikussaleh dan Institut Pertanian Bogor sebagai penemu dan pelaksana program demplot varietas padi IPB 3S. Data-data yang terkumpul ditabulasi dan dianalisis menggunakan uji statistik deskriptif dan menggunakan program Microsoft Excel, analisis statistikinferensialmenggunakan program Statistical Product and Service Solution (SPSS) versi 24. Berdasarkan hasil uji validitas yang dilakukan pada 30 orang anggota kelompok petani pengguna padi IPB 3S di Kabupaten Karawang yang memiliki karakteristik yang sama diperoleh hasil bahwa sebagian besar butir pernyataan dalam instrumen penelitian tergolong valid. Hal ini terlihat dari nilai $r$ hitung yang berkisar 0,353 sampai dengan 0,976. Adapun nilai alpha cronbachs yang dihasilkan berkisar dari 0,854 hingga 0,991 yang menunjukkan lebih besar dari $r$ tabel $(0,361)$ sehingga reliabel untuk digunakan.

\section{Hasil dan Pembahasan}

\section{Penguatan Kelembagaan Petani pelaksana Teknologi IPB Prima}

Kelembagaan petani di Desa Meunasah Pulo meliputi kelompok tani dan gabungan kelompok tani. Penguatan kelembagaanpetaniadalahpengembanganyangdiarahkan pada (a) penguatan struktur kelembagaan petani; (b) peningkatan kemampuan anggota dalam pengembangan agribisnis; dan (c) peningkatan kemampuan kelembagaan petani dalam menjalankan fungsinya. Menurut Babang (2008) penguatan kelompok merupakan cara strategis untuk memberi solusi pemecahan masalah dalam usaha berdasarkan pada hasil identifikasi masalah dan potensi secara bersama-sama dengan stakeholder.

Berdasarkan hasil penelitian dapat dilihat bahwa petani setuju kelembagaan petani berfungsi sebagai penguatan struktur kelembagaan petani, peningkatan kemampuan anggota dalam pengembangan agribisnis dan peningkatan kemampuan kelembagaan petani dalam menjalankan fungsinya. Secara umum hal tersebut dapat terjadi karena kelembagaan petani yang ada di Desa Meunasah Pulo tetap berusaha untuk meningkatkan fungsinya agar tercapai tujuan yang diinginkan. Secara lebih terinci terlihat pada Tabel 1.

Penguatan struktur kelembagaan petani merupakan 
Tabel 1. Distribusi Responden berdasarkan Penguatan Kelembagaan Petani

\begin{tabular}{llrr}
\hline \multicolumn{1}{c}{ Penguatan Kelembagaan Petani } & Skala Pengukuran & Jumlah & $\begin{array}{c}\text { Persentase } \\
(\mathbf{\%})\end{array}$ \\
\hline Penguatan struktur kelembagaan petani & Tidak setuju & 0 & 0 \\
& Kurang setuju & 3 & 6 \\
& Setuju & $\mathbf{3 8}$ & $\mathbf{7 6}$ \\
& Sangat setuju & 9 & 18 \\
Peningkatan kemampuan anggota dalam pengembangan & Tidak setuju & 0 & 0 \\
agribisnis & Kurang setuju & 12 & 24 \\
& Setuju & $\mathbf{3 8}$ & $\mathbf{7 6}$ \\
& Sangat setuju & 0 & 0 \\
Peningkatan kemampuan kelembagaan petani dalam & Tidak setuju & 0 & 0 \\
menjalankan fungsinya & Kurang setuju & 6 & 12 \\
& Setuju & $\mathbf{4 1}$ & $\mathbf{8 2}$ \\
\hline
\end{tabular}

Keterangan: $\quad \mathrm{n}=50$

sesuatu yang ingin dicapai oleh kelembagaan petani. Sebesar 80 persen petani setuju bahwa kelembagaan petani yang ada di Desa Meunasah Pulo telah melakukan kegiatan penguatan struktur kelembagaan petani padi baik dalam hal pengembangan pondasi dasar kelembagaan petani yang meliputi aturan/norma, rutinitas pertemuan, penyusunan perencanaan, fasilitasi usaha bersama, sebagai sumber pelayanan informasi dan teknologi serta mampu memfasilitasi pemupukan modal usaha. Hal ini berarti bahwa petani mengetahui serta berperan dalam penguatan struktur kelembagaan petani tersebut.

Wibowo (2005) menjelaskan strategi penguatan kelompok dilihat dari aspek kelembagaan dan aspek sosial. Strategi penguatan kelembagaan yang meliputi struktur dan kultur kelompok, merupakan suatu strategi yang diarahkan untuk memperbaiki struktur dan kultur dari kelompok. Strategi penguatan sosial, yaitu strategi yang diarahkan untuk memperbaiki aspek sosial yang meliputi penumbuhan motivasi berkelompok, peran masyarakat guna mendukung pengembangan kelompok, mempererat interaksi dalam kelompok, meningkatkan kepedulian sosial antar anggota kelompok, dan memantapkan sikap atau rasa memiliki, menumbuhkan solidaritas sosial, kohesivitas sosial dan integrasi sosial sehingga bantuan dianggap sebagi amanah yang harus dipertanggungjawabkan secara sosial.

Peningkatan kemampuan anggota dalam pengembangan agribisnis merupakan usaha kelembagaan petani untuk meningkatkan kemampuan petani dalam menganalisis peluang usaha, potensi pasar, potensi wilayah dan sumber daya, mengelola usahatani dan akses informasi serta permodalan. Pada penelitian sebesar 76 persen petani setuju kelembagaan petani telah melakukan berbagai usaha peningkatan kemampuan anggota dalam pengembangan agribisnis.

Namun hasil observasi di lapangan, peran kelembagaan petani dalam pengembangan agribisnis petani masih tergolong lemah, hal ini disebabkan karena pertemuan antar anggota kelompok yang tidak dilaksanakan secara berkala dan bersifat formal. Pertemuan yang tidak terjadwal menyebabkan penyebaran informasi menjadi tidak merata. Budaya petani di Provinsi Aceh lebih senang ketika melakukan pertemuan di warung kopi, namun pertemuan tersebut tidak tersruktur, materi yang dibahas juga tidak disusun terlebih dahulu, sehingga informasi yang disampaikan tidak dibahas secara mendalam.

Menurut Hermanto dan Swastika (2011) untuk melakukan penguatan kelompok yang harus dilakukan adalah meningkatkan kemampuan kelompok dalam hal memahami kekuatan (potensi) dan kelemahan (masalah) kelompok, memperhitungkan peluang dan tantangan yang dihadapi pada masa saat ini dan masa mendatang, memilih berbagai alternatif pemecahan masalah dan menyelenggarakan kehidupan berkelompok yang serasi 
dengan lingkungannya secara berkesinambungan.

Peningkatan kemampuan kelembagaan petani dalam menjalankan fungsinya merupakan kegiatan pembinaan yang dilaksanakan secara berkesinambungan dan diarahkan pada upaya peningkatan kemampuan kelompok dalam melaksanakan fungsinya sebagai kelas belajar, wahana kerja sama dan unit produksi. Pada penelitian sebesar 82 persen petani setuju bahwa kelompok telah melaksanakan fungsinya sebagai kelas belajar, wahana kerja sama dan unit produksi. Hal ini dapat dilihat dengan adanya kegiatan diskusi antar petani, walaupun hal ini tidak dilakukan secara formal. Selanjutnya di Desa Meunasah Pulo telah dibentuk koperasi yang dapat dimanfaatkan bagi petani untuk mengakses modal, sebagai bentuk kerja sama antar petani.

Gabungan Kelompok Tani Sepakat telah memiliki gudang gabah sendiri, sebagai upaya mengumpulkan gabah dari seluruh anggota yang nantinya pedagang pengumpul akan mengambil dari gudang tersebut. Abdullah (2008) menyampaikan bahwa anggota kelompok peternak sapi potong diharapkan dapat saling berinteraksi dan bekerjasama, sehingga mempunyai dampak saling membutuhkan, saling meningkatkan, salingmemperkuat, sehingga akan meningkatkan pengetahuan dan kemampuan dalam mengelolasistem usaha agribisnis dan agroindustri secara potensial.

\section{Keputusan Adopsi Teknologi IPB Prima}

Anggota Gabungan Kelompok Tani Sapu Pakat yang mengikuti kegiatan pendampingan sebagai penangkar benih Varietas IPB 3S telah mendapatkan berbagai informasi mengenai cara budidaya tanaman padi dengan Teknologi IPB Prima. Empat komponen yang harus dilakukan yaitu 1) melakukan restorasi lahan dengan jerami, 2) aplikasi IPB-Bio, 3) IPB-Best practice, dan 4) penerapan mekanisasi pertanian. Pada penelitian dapat dilihat sejauhmana keputusan petani dalam menerapkan komponen-komponen Teknologi IPB Prima tersebut. Secara lebih terinci penjelasan masing-masing keputusan adopsi Teknologi IPB Prima dapat dilihat pada Tabel 2.

Pemanfaatan kembali jerami di lahan pertanian merupakan upaya mengurangi penggunaan pupuk kimia, sebab jerami dapat bermanfaat menjadi pupuk organik bagi tanah. Pada penelitian tingkat adopsi petani terhadap kegiatan pengembalian jerami pada lahan pertanian menunjukkan kategori sering sebesar 48 persen. Sebagian besar petani langsung meninggalkan jerami saat panen hingga membusuk dengan sendirinya, adapula yang membakarnya. Menurut LPPM

Tabel 2. Distribusi Responden berdasarkan Keputusan Adopsi Teknologi IPB Prima, Tahun 2018

\begin{tabular}{|c|c|c|c|c|}
\hline No. & Keputusan Adopsi Teknologi IPB Prima & Skala Pengukuran & Jumlah & Presentasi \\
\hline \multirow[t]{4}{*}{1} & Pemanfaatan kembali jerami & Tidak pernah & 15 & 30,0 \\
\hline & & Jarang & 11 & 22,0 \\
\hline & & Sering & 24 & 48,0 \\
\hline & & Selalu & 0 & 0,0 \\
\hline \multirow[t]{4}{*}{2} & Aplikasi IPB-BIO & Tidak pernah & 37 & 74 \\
\hline & & Jarang & 13 & 26 \\
\hline & & Sering & 4 & 8 \\
\hline & & Selalu & 0 & 0 \\
\hline \multirow[t]{4}{*}{3} & IPB-Best practice & Tidak pernah & 0 & 0 \\
\hline & & Jarang & 0 & 0 \\
\hline & & Sering & 22 & 44 \\
\hline & & Selalu & 28 & 56 \\
\hline \multirow[t]{4}{*}{4} & Penerapan mekanisasi & Tidak pernah & 3 & 6 \\
\hline & & Jarang & 45 & 90 \\
\hline & & Sering & 2 & 4 \\
\hline & & Selalu & 0 & 0 \\
\hline
\end{tabular}

Keterangan:

$$
\mathrm{n}=50
$$


IPB (2016) manfaat restorasi lahan dengan jerami diantaranya: a) sumber bahan organik mudah dan murah; b) memperbaiki kesuburan biologi tanah; c) meningkatkan daya pegang air; d) meningkatkan musuh alami, menekan OPT; e) mengurangi dosis pupuk NPK; f) menyeimbangkan unsur hara tanah (menyehatkan tanah); dan g) adaptasi terhadap perubahan iklim global. Aplikasi IPB-Bio merupakan kegiatan penggunaan bakteri dekomposer yang bermanfaat untuk membantu dekomposisi jerami, penggunaan mikroba parasit, dan penggunaan pupuk IPB Bio pada pengolahan tanah kedua. Menurut LPPM IPB (2016) bakteri ini mampu menambat $\mathrm{N}$, melarutkan $\mathrm{P}$ dan $\mathrm{K}$, agen hayati menekan patogen, PGPR untuk merangsang pertumbuhan tanaman. Cara pemakaiannya dengan diinkubasikan pada pupuk organik. Pada kegiatan demplot petani mendapatkan materi mengenai aplikasi IPB Bio dan telah melakukan dekomposer jerami serta aplikasi IPB Bio. Namun, pasca demplot petani tidak lagi mengolah jerami menjadi pupuk kompos dengan alasan efisensi waktu, dan tidak tersedianya pupuk IPB Bio. Hal ini dapat dilihat dari hasil penelitian yang menunjukkan bahwa sebesar 74 persen petani tidak pernah melakukan dekomposisi jerami dengan bakteri dekomposer.

IPB-Best practice merupakan perlakuan khusus yang dilakukan terhadap benih dan lahan pertanian. LPPM IPB (2016) menyusun standar perlakuan terhadap benih dan lahan khususnya pada saat penanaman Padi Varietas IPB 3S yang terdiri dari 1) penggunaan varietas unggul ipb, 2) benih bersertifikat, 3) melakukan penyiangan lahan terpadu, 4) persemaian terkendali, 5) penanaman terkendali, 6) pengairan dengan sistem macak-macak, 7) pemupukan terkendali, 8) pengendalian OPT, 9) waktu panen dan perlakuan pasca panen yang tepat, serta 10) kemampuan bekerjasama dengan pihak swasta dalam bidang pemasaran. Petani di Desa Meunasah Pulo digolongkan pada petani dengan kategori lanjut, dengan indikator seperti rata-rata umur petani, lamanya keanggotaan dalam kelompok tani, serta kemampuan petani dalam usahatani padi. Para petani sudah sangat paham dengan setiap perlakuan yang tepat terhadap benih dan lahan. Hal ini dapat dilihat dari hasil penelitian, bahwa sebesar 56 persen petani telah melakukan perlakuan benih dan lahan berdasarkan aturan IPB-Best practice.

Penerapan mekanisasi pertanian merupakan kegiatan menggunakan alat dan mesin pertanian yang sesuai dengan anjuran IPB. Penggunaan alat dan mesin pertanian yang mampu meningkatkan efektivitas dan efisiensi kegiatan budidaya tanaman padi seperti: a) Penyiapan lahan (menggunakan traktor pengolah tanah); b) Pembibitan (mesin penyemai benih padi); c) Penanaman menggunakan mesin tanam padi; d) Pemupukan dengan mesin semprot pupuk; e) Pemanenan dilakukan dengan (Combine harvester) mesin panen padi, minimal dengan sabit kemudian dirontok menggunakan (power thresher) mesin perontok padi. Berdasarkan hasil penelitian sebesar 90 persen petani masih jarang menggunakan mesin pertanian, hal ini dapat disebabkan oleh 1) lahan pertanian yang tidak mendukung penggunaan mesin panen padi, 2) kemampuan petani dalam mengoperasikan mesin pertanian masih rendah, serta 3) kehadiran mesin panen padi masih tergolong baru, yaitu dua kali musim tanam terakhir.

\section{Pengaruh Penguatan Kelembagaan Petani terhadap Pengambilan Keputusan Adopsi Teknologi IPB Prima}

Penguatan kelembagaan petani melalui kegiatan penyuluhan mengenai teknologi terbarukan sebagai upaya: a) memudahkan petani dalam mengakses informasi melalui kegiatan penyuluhan yang dilakukan di kelompok, b) memudahkan petani mengakses saprodi, sebab pemerintah mengarahkan bahwa jika petani ingin mendapatkan subsidi maka harus mengikuti kelompok, c) mempercepat petani dalam mengadopsi teknologi terbarukan, d) meningkatkan kemandirian dan kerjasama kelompok dan e) meningkatkan pendapatan dan kesejahteraan petani (Deptan 2002). Hal ini senada dengan Anantanyu (2011) bahwa kelembagaan petani di pedesaan sangat berkontribusi dalam pengembangan sosial ekonomi petani; akses informasi pertanian; akses modal, infrastruktur, dan pasar; dan adopsi inovasi pertanian. Secara lebih terinci pengaruh penguatan kelembagaan petani terhadap keputusan adopsi Teknologi IPB Prima dapat dilihat pada Tabel 3.

Hasil penelitian menunjukkan bahwa peningkatan kemampuan kelembagaan petani dalam menjalankan fungsinya berpengaruh nyata terhadap aplikasi IPBBio sebesar 0,315 dan 0,417 terhadap pelaksanaan IPB Best-Practice. Kemampuan kelembagaan petani dalam menjalankan fungsinya sebagai kelas belajar, wahana kerja sama dan unit produksi mampu memfasilitasi 
Tabel 3. Nilai Koefisien Regresi Penguatan Kelembagaan Petani terhadap Keputusan Adopsi Teknologi IPB Prima, Tahun 2018

\begin{tabular}{|c|c|c|c|c|c|}
\hline \multirow[b]{2}{*}{ No. } & \multirow[b]{2}{*}{ Penguatan Kelembagaan Petani } & \multicolumn{4}{|c|}{$\begin{array}{c}\text { Nilai Koefisien ( } \beta \text { ) terhadap Keputusan Adopsi } \\
\text { Teknologi IPB Prima }\end{array}$} \\
\hline & & $\begin{array}{c}\text { Pemanfaatan } \\
\text { kembali } \\
\text { Jerami }\end{array}$ & $\begin{array}{l}\text { Aplikasi } \\
\text { IPB-Bio }\end{array}$ & $\begin{array}{l}\text { IPB Best } \\
\text { Practice }\end{array}$ & $\begin{array}{l}\text { Penerapan } \\
\text { Mekanisasi }\end{array}$ \\
\hline 1 & Penguatan struktur kelembagaan petani & $-0,450$ & 0,216 & 0,057 & 0,011 \\
\hline 2 & $\begin{array}{l}\text { Peningkatan kemampuan anggota dalam } \\
\text { pengembangan agribisnis }\end{array}$ & $-0,860 * *$ & 0,123 & $-0,140$ & $-0,136$ \\
\hline 3 & $\begin{array}{l}\text { Peningkatan kemampuan kelembagaan petani } \\
\text { dalam menjalankan fungsinya }\end{array}$ & $-0,166$ & $0,315^{*}$ & $0,417 *$ & $-0,120$ \\
\hline 26 & $\begin{array}{l}* \text { berpengaruh nyata pada } \mathrm{p} \leq 0,05 \\
* * \text { berpengaruh sangat nyata pada } \mathrm{p} \leq 0\end{array}$ & & & & \\
\hline
\end{tabular}

petani dalam mengembangkan pengetahuan petani mengenai aplikasi bakteri dekomposer walaupun belum kepada tahap penerapan. Selanjutnya, peran kelembagaan petani mampu memfasilitasi pelaksanaan sepuluh indikator IPB-Best practice seperti yang telah disebutkan sebelumnya.

Peningkatan kemampuan anggota dalam pengembangan agribisnis berpengaruh nyata negatif terhadap pemanfaatan kembali jerami sebesar 0,860. Kemampuan petani dalam mengefisiensi waktu sebagai implementasi pengembangan kemampuan agribinis petani, maka akan semakin memengaruhi petani untuk dapat meningkatkan kecepatan kegiatan usahatani, diantaranya perlakuan terhadap jerami. Membakar jerami merupakan usaha efisiensi waktu, sebab mengolah jerami akan membutuhkan waktu dan tenaga lebih banyak.

Berbagai indikator pada penguatan struktur kelembagaan petani yang tidak berpengaruh dapat disebabkan oleh masih rendahnya peran kelembagaan petani dalam pengambilan keputusan adopsi teknologi serta pengaruh lain di luar model. Hal ini senda dengan penelitian Prasetyo dan Awaludin (2016) bahwa berbagai teknologi pertanian sudah banyak diketahui oleh petani, namun dibutuhkan kelembagaan petani yang kuat untuk menyebarluaskannya inovasi tersebut sehingga proses adopsi teknologi oleh anggota kelompok dapat berjalan dengan baik.

Menurut Zulvera (2014) Proses pengambilan keputusan adopsi inovasi dipengaruhi berbagai peubah, yang dapat dikelompokkan atas: a) peubah karakteristik penerima inovasi, seperti: pendidikan, umur, pengalaman usahatani, sikap terhadap inovasi, keterbukaan terhadap informasi; b) peubah karakteristik inovasi, yang diukur berdasarkan persepsi penerima inovasi terhadap sifat inovasi, yaitu tingkat relatif advantage, kompleksitas, kompatibilitas, keteramatan dan triability; c) peubah lingkungan, yang terdiri dari dukungan terhadap kegiatan usahatani, seperti ketersediaan sarana produksi, harga, jaminan pasar, sarana transportasi dan telekomunikasi, tersedianya kredit, pengaruh sistem sosial dimana penerima inovasi berada; d) proses pembelajaran yang dilakukan penerima inovasi, seperti keikutsertaan dalam penyuluhan, pelatihan, tingkat komunikasi dengan berbagai sumber informasi, motivasi dari sumbersumber informasi.

\section{Kesimpulan}

Petani setuju kelembagaan petani telah melakukan penguatan struktur kelembagaan petani, peningkatan kemampuan anggota dalam pengembangan agribisnis dan peningkatan kemampuan kelembagaan dalam menjalankanfungsinya.PadakeputusanadopsiTeknologi IPB Prima, petani telah memanfaatkan kembali jerami pada lahan pertanian dan telah melaksanakan budidaya tanaman padi sesuai dengan anjuran IPB-Best Practice, namun petani belum pernah melakukan dekomposisi jerami menggunakan dekomposer dan masih jarang dalam penerapan mekanisasi pertanian. Peningkatan 
kemampuan kelembagaan petani dalam menjalankan fungsinya berpengaruh nyata terhadap aplikasi IPB Bio dan pelaksanaan IPB Best-Practice. Kemudian peningkatan kemapuan anggota dalam pengembangan agribisnis khususnya efisiensi waktu berpengaruh nyata negatif terhadap pemanfaatan kembali jerami, dengan membakar jerami di lahan pertanian."

\section{Daftar Pustaka}

Abdullah A. 2008. Peranan penyuluhan dan kelompok tani ternak untuk meningkatkan adopsi teknologi dalam peternakan sapi potong. Prosiding Seminar Nasional Sapi Potong, Palu (ID). Fakultas Peternakan Universitas Hasanuddin Makassar Sulawesi Selatan (ID).

Anantanyu S. 2011. Kelembagaan Petani: Peran dan Strategi Pengembangan Kapasitasnya. Jurnal Sosial Ekonomi Pertanian dan Agribisnis. (SEPA) 7 (2) 102-109. ISSN 1829-9946

Aswidinnor H, Willy B. Suwarno, Desta Wirnas, Yudiwanti We Kusumo. 2016. Teknologi Produksi Optimum (IPB-Prima) Padi Varietas IPB 3S dan IPB 4S. Departemen Agronomi Dan Hortikultura. Fakultas Pertanian. Institut Pertanian Bogor.

[Deptan] Departemen Pertanian. 2002. Pedoman Umum Pemberdayaan Masyarakat Agribisnis Melalui Penguatan Modal Usaha Kelompok. Jakarta (ID). Departemen Pertanian.

Hermanto KS dan D Swastika. 2011. Penguatan kelompok tani: langkah awal peningkatan kesejahtraan petani. Jurnal Analisis Kebijakan Pertanian. Vol. 9: 371-390.

LPPM-IPB. 2016. Pendampingan Model AgribisnisAplikasi Teknologi IPB Prima pada Padi Sawah. [dapat diunduh di http://lppm.ipb.ac.id/leafletaplikasi-teknologi-ipb-prima-pada-padi-sawah/]

Nirwani P, Dompak N, Pera N. 2012. Pengaruh Foto dan Lukisan Pada Buklit terhadap Peningkatan Pengetahuan Petani Padi Sawah tentang Pupuk Organik di Desa Lagan Hulu. Jurnal Sosial Ekonomika Bisnis. 1412-8241.

[Permentan] Peraturan Menteri Pertanian Republik Indonesia. Nomor 67 tahun 2016 tentang Pembinaan Kelembagaan Petani.

Prasetyo AF dan Awaludin A. 2016. Peran Kelembagaan Peternak Dalam Adopsi Teknologi. Jurnal Ilmiah INOVASI. 1 (2): 1411-5549

[Pusluhtan] Pusat Penyuluhan Pertanian. 2016. Petunjuk
Pelaksanaan Pembinaan Kelompok Tani-Nelayan. Jakarta (ID). Departemen Pertanian.

2018. Sistem Penyuluhan Pertanian. Jakarta (ID). Departemen Pertanian.

Zakaria WA. 2009. Penguatan Kelembagaan Kelompok Tani Kunci Kesejahteraan Petani. Seminar Nasional Dinamika Pembangunan Pertanian dan Perdesaan. Prosiding Seminar Nasional Dinamika Pembangunan Pertanian dan Perdesaan

Zamzami M. 2017. Analisis Komparatif Usahatani Padi Sawah Varietas IPB 3S dengan Varietas Ciherang di Gampong Meunasah Pulo Kecamatan Sawang Kabupaten Aceh Utara. [Skripsi]. Aceh Utara (ID). Universitas Malikussaleh. 